\title{
The Comparative Advantage of Plain Radiography in Diagnosis of Obstruction of the Small Intestine in Dogs
}

\author{
J. ZATLOUKAL ${ }^{1}$, M. CRHA ${ }^{2}$, J. LORENZOVÁ ${ }^{2}$, R. HUSNÍK ${ }^{3}$, P. KOHOUT ${ }^{1}$, A. NEČAS ${ }^{2}$ \\ ${ }^{1}$ Department of Diagnostic Imaging, Small Animal Clinic, University of Veterinary and Pharmaceutical \\ Sciences, Brno, Czech Republic \\ ${ }^{2}$ Department of Surgery and Orthopaedics, Small Animal Clinic, University of Veterinary \\ and Pharmaceutical Sciences, Brno, Czech Republic \\ ${ }^{3}$ Department of Internal Medicine, Small Animal Clinic, University of Veterinary \\ and Pharmaceutical Sciences, Brno, Czech Republic \\ Received August 15, 2003 \\ Accepted July 29, 2004
}

\section{Abstract}

Zatloukal J., M. Crha, J. Lorenzová, R. Husník, P. Kohout, A. Nečas: The Comparative Advantage of Plain Radiography in Diagnosis of Obstruction of the Small Intestine in Dogs. Acta Vet. Brno 2004, 73: 365-374.

A total of 53 and 66 dogs with and without small intestinal obstruction, respectively, were included into the study to determine the diagnostic yield of plain radiography for the diagnosis of intestinal obstruction compiling all radiological signs. Plain radiographs were examined by specialists in radiology, surgery and internal medicine and the differences in the evaluation by individual specialists were not statistically significant. Accuracy, sensitivity and specificity of plain radiographs in the diagnostics of small intestinal obstruction varied from $80.7,76.8$ and $88.2 \%$ to $89.1,87.0$ and $90.8 \%$, respectively. When a radiologist determined the diagnosis to be final, accuracy and the predictive value of the final positive radiological diagnosis rose up to 96.9 and $100 \%$, respectively. Plain radiography resulted in a high diagnostic yield in cases of simple intraluminal obstruction by a foreign body ( 75 to $80 \%$ of correct diagnoses) and intestinal obstruction $(80$ to $85 \%)$. The diagnostic yield in other causes of intestinal obstruction (linear foreign bodies, invagination, adhesions or strictures) was lower and depended mostly on the experience of the evaluating specialist. Plain radiography resulted in a correct diagnosis only in a few cases of diseases not causing small intestinal obstruction such as gastroenteritis, parvovirosis, pancreatitis and renal failure. Plain radiography, nevertheless, is of great importance for ruling out small intestinal obstruction, because it has a predictive value of negative results in 80.3 to $90.9 \%$ of cases.

Considering the obtained results, we can recommend plain radiography as a simple primary diagnostic imaging method of intestinal obstruction.

Foreign body; intussusception; gastroenteritis; pancreatitis; intestinal dilatation

Small intestinal obstruction belongs to less frequent but important diseases in the dog and other animal species as well in humans (Strombeck and Guilford 1991). The intestinal obstruction is classified according to pathophysiological changes as a simple mechanical obstruction or strangulation (E1lis on 1993).

The simple mechanical obstruction results primarily in either partial or complete obstruction of intestinal lumen and then secondarily in blood supply disturbance. There are three types of mechanical obstruction: intraluminal (foreign bodies), intramural (neoplasia or granulomas) and extraluminal (adhesions, pancreatic masses, herniae). The most frequent cause of intestinal obstruction in dogs is foreign body. Strangulation of small intestine refers to intestinal obstruction and considerable impairment of the blood flow. It is most commonly due to intussusception, intestinal volvulus, strangulation of small intestine in diaphragmatic, inguinal or abdominal hernia and, sometimes, mesenteric avulsions and arterial thrombosis (Ellis on 1993). 
The diagnostics of small intestinal obstruction is based on a thorough clinical examination and identification of the obstruction using diagnostic imaging methods. Patients are mostly presented with a history of vomiting and/or diarrhea, abdominal pain, lethargy and anorexia. On clinical examination it is sometimes possible to palpate the foreign body or invagination. Effusions within the abdominal cavity may result in positive ballottement. Diagnostic imaging methods used widely in veterinary practice are radiography and ultrasonography. Radiography may directly reveal the foreign body, intraabdominal masses, invagination or changes in the position of small intestine. Ileus manifested by small intestinal distension by gas and/or fluids proximally to the site of obstruction or the whole intestinal section strangulated is another radiological sign indicative of the small intestinal obstruction on plain radiographs (Gibbs and Pearson 1973; Wilson and Burt 1974; Graham et al. 1998; Cairó et al. 1999; Hosg ood et al. 1992). Ultrasonography is important especially in the detection of the small intestinal intussusception and neoplasia (Penninck et al. 1990; Myers and Penninck 1994; Lamb and Mantis 1998; Levitt and Bauer 1992; Lewis and Ellis on 1987; Válek et al. 1997; Válek and Hrobař 1997). In many cases it was also very good at visualisation of intraluminal foreign bodies (Manczur et al. 1998). Radiographic and ultrasonographic examinations are also important for the diagnosis of abdominal effusion and free intraabdominal gas due to intestinal rupture or peritonitis (Henley et al. 1989). The final diagnosis of small intestinal obstruction, sometimes, lies on the upper gastrointestinal study, barium enema, enteroclysis, computer tomography or angiography (Gibbs and Pearson 1973; McPhedran et al. 1970; Wilson and Burt 1974; Levitt and Bauer 1992; Lewis and Ellison 1987; Wolvekamp 1989; Válek et al. 2000a; Válek et al. 2000b).

Despite of considerable advances of diagnostic methods for small intestinal obstruction, plain radiography remains the basic one. A whole number of radiological signs of small intestinal obstruction on plain radiographs, however, may be lacking especially in cases of a partial mechanical obstruction. These cases may then give a lot of false negative results (Gibbs and Pearson 1973; Wilson and Burt 1974; Graham et al. 1998; Cairó et al. 1999; Hosgood et al. 1992). On the other hand, a number of diseases may present radiological signs commonly attributed to the small intestinal obstruction (Arrick and Kleine 1987; Farow 1997; Graham et al. 1998; Lamb and France 1994; Moore and Carpenter 1984). To our knowledge, until now there has not been published an extensive study on the occurrence of both false positive and negative diagnoses of small intestinal obstruction on the basis of plain radiography. It was the objective of our study to fill this gap in knowledge and evaluate the yield of plain radiography in the diagnostics of small intestinal obstruction in the dog.

\section{Materials and Methods}

A total of 119 dogs treated at the Small Animal Clinic from January 1998 to April 2001 have been included into the study. The small intestinal obstruction was confirmed by laparotomy in 53 patients. Out of these patients, simple intraluminal obstruction by foreign bodies, linear foreign bodies, invagination, adhesions, mesenteric hernia, mesenteric volvulus and stricture was found in 40,4, 4, 2, 1, 1 and 1 cases, respectively. The control group included 66 patients suffering without any doubt from other problems than the small intestinal obstruction and in which the possibility of the small intestinal obstruction was ruled out either by long-term observation, laparotomy, or autopsy. The control group included only patients presented with vomiting as the main and initial clinical sign. The final diagnosis in patients of the control group included renal failure, parvovirosis, gastroenteritis of other couse than parvovirosis (haemorrhagic, dietetic and viral one) and pancreatitis in $28,11,22$ and 5 cases, respectively.

The initial examination of all patients was followed by taking laterolateral and ventrodorsal radiographs of the abdominal cavity. For purposes of this study the radiographs were evaluated by three specialists - radiologist (JZ), gastroenterologist (RH) and soft-tissue surgeon (JL). These evaluations were done 6 month after the last diagnosis was established to exclude the possibility of remembering the particular case. The evaluating persons were made acquainted with the possible diagnoses, in individual patients; however, they were not provided with any data other 
than the plain radiographs. Each of the evaluating persons recorded in the patient if he or she is able to confirm or exclude the diagnosis of intestinal obstruction on the basis of plain radiographs or if further examinations of the digestive tract are needed to distinguish from a final or suspect diagnosis. Diagnosis was recorded as a final or suspect diagnosis, but a radiological diagnosis was determined by the evaluating person in all cases.

The following terms were defined for purposes of the study. A true-positive diagnosis was defined as radiological diagnosis of small intestinal obstruction in a dog with definitive diagnosis of small intestinal obstruction. A falsepositive diagnosis was defined as radiological diagnosis of small intestinal obstruction in a dog without definitive diagnosis of small intestinal obstruction. A true-negative diagnosis was defined as radiological diagnosis of no small intestinal obstruction in a dog without definitive diagnosis of small intestinal obstruction. A false-negative diagnosis was defined as radiological diagnosis of no small intestinal obstruction in a dog with definitive diagnosis of small intestinal obstruction. Accuracy represented the probability of the correct radiological diagnosis, regardless of whether positive or negative. Adding the number of true-positive and true-negative results and dividing the sum by the total number of all cases calculated accuracy. Sensitivity represented the probability of true positive diagnosis. Sensitivity was calculated by dividing the number of true-positive results by the number of truepositive and false-negative results. Specificity represented the probability of true negative diagnosis. Specificity was calculated by dividing the number of true-negative results by the number of true-negative and false-positive results. The predictive value of a positive result represented the probability that a dog with radiological diagnosis of small intestinal obstruction had really definitive diagnosis of small intestinal obstruction. It was calculated by dividing the number of true-positive results by the number of true-positive and false-positive results. The predictive value of a negative result represented the probability that a dog with radiological diagnosis of small intestinal obstruction really did not have any small intestinal obstruction. It was calculated by dividing the number of truenegative results by the number of true-negative and false-negative results. Similar methods as for overall cases were used for cases with a final and suspect radiological diagnosis.

The $\chi 2$-test was used to compare results of individual evaluating persons and groups of diseases.

\section{Results}

Accuracy, sensitivity, specificity, predictive values of a positive result and predictive values of a negative result are described in Table 1. Even though individual evaluating persons differ in the parameters, in the predictive value of positive results even more than $13 \%$, the differences are not statistically significant. When evaluating radiographs, the surgeon achieved higher specificity and predictive values of positive results than the gastroenterologist, who, on the other hand had better sensitivity and predictive values of negative results. The radiologist had best results nearly in all parameters when evaluating plain radiographs with accuracy of $89.1 \%$.

Table 1

Contribution of plain radiography to the diagnosis of small intestinal obstruction

\begin{tabular}{|l|c|c|c|}
\hline & radiologist & surgeon & gastroenterologist \\
\hline Accuracy (\%) & 89.1 & 80.7 & 84.0 \\
\hline Sensitivity (\%) & 87.0 & 76.8 & 87.0 \\
\hline Specificity (\%) & 90.8 & 84.1 & 82.2 \\
\hline Predictive value of positive results (\%) & 88.7 & 81.1 & 75.5 \\
\hline Predictive value of negative results (\%) & 89.4 & 80.3 & 90.9 \\
\hline
\end{tabular}

Radiologist and gastroenterologist seemed to be more cautious than the surgeon when establishing the final diagnosis from plain radiographs $\left(\chi^{2}\right.$ test; $\left.p<0.01\right)$. On the basis of plain radiographs they came to the final diagnosis in 53.8 and $57.1 \%$ of cases, respectively. The surgeon seemed to be more straightforward in the evaluation and came to the final diagnosis on the basis of plain radiographs in $92.4 \%$ of cases. Considering suspect and final radiological diagnoses, there were more profound differences between individual evaluating persons than in the evaluation of all patients (Table 2). Thus, accuracy of final radiological diagnosis was significantly worse in the surgeon than in the radiologist $\left(\chi^{2}\right.$ test; $\left.p<0.05\right)$. Accuracy of suspect radiological diagnosis was significantly worse in the surgeon than in the radiologist $\left(\chi^{2}\right.$ test; $\left.p<0.01\right)$ and the gastroenterologist $\left(\chi^{2}\right.$ test; $\left.p<0.05\right)$. 
Table 2

Contribution of plain radiography to the diagnosis of small intestinal obstruction if the diagnosis was determined as definitive or suspected

\begin{tabular}{|l|c|c|c|}
\hline & radiologist & surgeon & gastroenterologist \\
\hline $\begin{array}{l}\text { Predictive value of final positive radiological } \\
\text { diagnosis (\%) }\end{array}$ & 100.0 & 71.2 & 93.9 \\
\hline $\begin{array}{l}\text { Predictive value of suspect positive } \\
\text { radiological diagnosis (\%) }\end{array}$ & 76.5 & 20.0 & 69.2 \\
\hline $\begin{array}{l}\text { Predictive value of final negative } \\
\text { radiological diagnosis (\%) }\end{array}$ & 93.3 & 86.4 & 94.3 \\
\hline $\begin{array}{l}\text { Predictive value of suspect negative } \\
\text { radiological diagnosis (\%) }\end{array}$ & 81.6 & 50.0 & 71.1 \\
\hline $\begin{array}{l}\text { Accuracy value of final radiological } \\
\text { diagnosis (\%) }\end{array}$ & 96.9 & 84.5 & 94.1 \\
\hline $\begin{array}{l}\text { Accuracy value of suspect radiological } \\
\text { diagnosis(\%) }\end{array}$ & 80.0 & 33.3 & 70.6 \\
\hline
\end{tabular}

Table 3 lists the number of true-positive and false-negative diagnoses of small intestinal obstruction and the number of final correct diagnoses on the basis of plain radiographs in individual disorders causing the small intestinal obstruction according to individual evaluating persons. Table 4 lists the number of true-negative and false-positive diagnoses of the intestinal obstruction and the number of final correct diagnoses on the basis of plain radiographs in individual disorders without small intestinal obstruction according to individual evaluating persons. The radiologist was significantly better than the surgeon in coming to the final correct diagnosis of renal failure $\left(\chi^{2}\right.$ test; $\left.p<0.05\right)$. The gastroenterologist was significantly better than the surgeon in coming to the final correct diagnosis of parvovirosis ( $\chi^{2}$ test, $\left.p<0.05\right)$, and ruling out the small intestinal obstruction in cases of gastroenteritis $\left(\chi^{2}\right.$ test, $\left.p<0.05\right)$.

\section{Discussion}

It is true that the small intestinal obstruction belongs to less frequent diseases of the gastrointestinal tract. It is, however, essential to rule it out in the patients presented with vomiting. Previous studies mention the small intestinal obstruction in $0.51 \%$ of dogs examined (Koike et al. 1981). The most common cause of the small intestinal obstruction is a simple intraluminal obstruction by foreign body. Intussusceptions and linear foreign bodies are less frequent. Adhesions, strictures, strangulation, mesenteric volvulus and neoplasia belong to rare causes of small intestinal obstruction. In this respect, our group of patients with small intestinal obstruction reflects the frequency of individual causes we encounter in a clinical practice or previous studies (B ohmer et al. 1990). The control group included patients with vomitus as the most evident sign, i.e. the most common clinical symptom of the intestinal obstruction. For purposes of simplification, only dogs suffering from a relatively narrow spectrum of diagnoses such as gastroenteritis, parvovirosis, renal failure and pancreatitis were included into the control group. The above-mentioned diseases belong to the most common ones with similar clinical signs as the small intestinal obstruction (Strombeck and Guilford 1991) and thus our results on the diagnostics of the small intestinal obstruction using plain radiography can be applied to the whole canine population.

No controlled study determining accuracy, specificity and sensitivity of plain radiographs in the diagnostics of the intestinal obstruction has yet been published. It is true that Grah am et al. (1998) examined plain radiographs in dogs with and without the intestinal obstruction, 
Table 3

Contribution of plain radiography to the diagnosis of specific small intestinal obstruction diseases

\begin{tabular}{|c|c|c|c|}
\hline & radiologist & surgeon & gastroenterologist \\
\hline \multicolumn{4}{|c|}{ Simple intraluminar obstruction with foreign body } \\
\hline True positive disease diagnosis & $32(80.0 \%)$ & $32(80.0 \%)$ & $30(75.0 \%)$ \\
\hline $\begin{array}{l}\text { False negative disease diagnosis with } \\
\text { true positive diagnosis of intestinal } \\
\text { obstruction }\end{array}$ & $2(5.0 \%)$ & $2(5.0 \%)$ & $2(5.0 \%)$ \\
\hline $\begin{array}{l}\text { False negative diagnosis of intestinal } \\
\text { obstruction }\end{array}$ & $6(15.0 \%)$ & $6(15.0 \%)$ & $8(20.0 \%)$ \\
\hline \multicolumn{4}{|l|}{ Linear foreign body } \\
\hline True positive disease diagnosis & $3(75.0 \%)$ & 0 & $1(25.0 \%)$ \\
\hline $\begin{array}{l}\text { False negative disease diagnosis with } \\
\text { true positive diagnosis of intestinal } \\
\text { obstruction }\end{array}$ & $1(25.0 \%)$ & $2(50.0 \%)$ & $1(25.0 \%)$ \\
\hline $\begin{array}{l}\text { False negative diagnosis of intestinal } \\
\text { obstruction }\end{array}$ & 0 & $2(50.0 \%)$ & $2(50.0 \%)$ \\
\hline \multicolumn{4}{|l|}{ Intussusception } \\
\hline True positive disease diagnosis & $2(50.0 \%)$ & 0 & 0 \\
\hline $\begin{array}{l}\text { False negative disease diagnosis with } \\
\text { true positive diagnosis of intestinal } \\
\text { obstruction }\end{array}$ & $2(50.0 \%)$ & $3(75.0 \%)$ & $3(75.0 \%)$ \\
\hline $\begin{array}{l}\text { False negative diagnosis of intestinal } \\
\text { obstruction }\end{array}$ & 0 & $1(25.0 \%)$ & $1(25.0 \%)$ \\
\hline \multicolumn{4}{|c|}{ Small intestine stricture or adhesion } \\
\hline True positive disease diagnosis & 0 & 0 & 0 \\
\hline $\begin{array}{l}\text { False negative disease diagnosis with } \\
\text { true positive diagnosis of intestinal } \\
\text { obstruction }\end{array}$ & $3(100.0 \%)$ & $2(66.7 \%)$ & $1(33.3 \%)$ \\
\hline $\begin{array}{l}\text { False negative diagnosis of intestinal } \\
\text { obstruction }\end{array}$ & 0 & $1(33.3 \%)$ & $2(66.7 \%)$ \\
\hline
\end{tabular}

radiographs, however, were evaluated only with regard to the degree of dilatation of small intestine. The evaluation in the above-mentioned study based on considering only one radiological sign of small intestinal obstruction cannot, therefore, be fully compared to our results. The limiting degree of dilatation of small intestine considered diagnostic for small intestinal obstruction is 1.95 -fold the width of the fifth lumbar vertebra. Considering this fact and Table 2 in the study by Grah a m et al. (1998) we get the following diagnostic yield: accuracy $73.3 \%$, sensitivity $57.1 \%$, specificity $82.7 \%$, the predictive value of a positive result $71.4 \%$ and the predictive value of a negative result $74.1 \%$. Then, our results would be considerably better than those ones of the above study. It is due to the way of evaluation of radiographs. In the study by Grah a m et al. (1998) considering only one sign of obstruction. We used a qualitative assessment of radiographs on the basis of all common criteria including both the primary (foreign body finding, intussusception visualization) and the secondary changes (small bowel dilatation by gas and/or fluids, focal accumulation of mineral or food debris, plication of small intestine, bunching of small intestinal loops, intraluminal asymmetrically located un-united gas bubbles) (Dennis et al. 2001; Gibbs and Pearson 1973).

The subsequent evaluation in our study was thus a subjective opinion of the evaluating person compiling all radiological signs and depended to a great degree on his or her experience. If he or she evaluated the finding on the radiograph without any doubt as 
Table 4

Contribution of plain radiography to the diagnosis of specific small intestinal non-obstruction diseases

\begin{tabular}{|c|c|c|c|}
\hline & radiologist & surgeon & gastroenterologist \\
\hline \multicolumn{4}{|l|}{ Gastroenteritis } \\
\hline True positive disease diagnosis & $12(54.5 \%)$ & $15(68.2 \%)$ & $12(54.5 \%)$ \\
\hline $\begin{array}{l}\text { False negative disease diagnosis with } \\
\text { true negative diagnosis of intestinal } \\
\text { obstruction }\end{array}$ & $7(31.8 \%)$ & 0 & $9(40.9 \%)$ \\
\hline $\begin{array}{l}\text { False positive diagnosis of intestinal } \\
\text { obstruction }\end{array}$ & $3(13.7 \%)$ & $7(31.8 \%)$ & $1(4.6 \%)$ \\
\hline \multicolumn{4}{|l|}{ Parvovirus enteritis } \\
\hline True positive disease diagnosis & $5(45.4 \%)$ & $1(9.1 \%)$ & $7(63.6 \%)$ \\
\hline $\begin{array}{l}\text { False negative disease diagnosis with } \\
\text { true negative diagnosis of intestinal } \\
\text { obstruction }\end{array}$ & $4(36.4 \%)$ & $8(72.7 \%)$ & $3(27.3 \%)$ \\
\hline $\begin{array}{l}\text { False positive diagnosis of intestinal } \\
\text { obstruction }\end{array}$ & $2(18.2 \%)$ & $2(18.2 \%)$ & $1(9.1 \%)$ \\
\hline \multicolumn{4}{|l|}{ Pancreatitis } \\
\hline True positive disease diagnosis & 0 & 0 & 0 \\
\hline $\begin{array}{l}\text { False negative disease diagnosis with } \\
\text { true negative diagnosis of intestinal } \\
\text { obstruction }\end{array}$ & $4(80.0 \%)$ & $4(80.0 \%)$ & $4(80.0 \%)$ \\
\hline $\begin{array}{l}\text { False positive diagnosis of intestinal } \\
\text { obstruction }\end{array}$ & $1(20.0 \%)$ & $1(20.0 \%)$ & $1(20.0 \%)$ \\
\hline \multicolumn{4}{|l|}{ Renal failure } \\
\hline True positive disease diagnosis & $13(46.4)$ & $6(21.4 \%)$ & $10(35.7 \%)$ \\
\hline $\begin{array}{l}\text { False negative disease diagnosis with } \\
\text { true negative diagnosis of intestinal } \\
\text { obstruction }\end{array}$ & $14(50.0 \%)$ & $19(67.9 \%)$ & $15(53.6 \%)$ \\
\hline $\begin{array}{l}\text { False positive diagnosis of intestinal } \\
\text { obstruction }\end{array}$ & $1(3.6 \%)$ & $3(10.7 \%)$ & $3(10.7 \%)$ \\
\hline
\end{tabular}

a foreign body (even in the absence of radiological signs of obstruction), radiographs were classified as showing small intestinal obstruction. The opinion that there is a small intestinal obstruction can be replaced by the opinion that it is necessary to perform a laparoscopic revision of the small intestine. Most cases of foreign bodies resulting in clinical signs such as vomiting and abdominal pain require surgical intervention (Strombeck and Guilford 1991). Laparotomy confirmed the obstruction requiring surgical treatment in all cases of small intestinal obstruction included into our study. If on the basis of plain radiography the diagnoses determined by the radiologist were unambiguous, there would be no case of uselessly performed laparotomy in our study (predictive value of a final positive radiological diagnosis $=100 \%$ ).

Diagnoses of small intestinal obstruction resulted in inter-examiner differences which were, however, not statistically significant. The more straightforward approach of the surgeon to determination of a final diagnosis on the basis of plain radiography partly influenced the comparison of results of individual evaluating persons considering the opinion of the evaluating person that it is possible to come unambiguously to a radiological diagnosis. There may be two causes of this problem. One of them is the more aggressive approach of surgeons to the diagnostics of diseases and the other one lies in their different criteria for the final and suspect radiological diagnosis. The considerable differences between the surgeon and the other two evaluating specialists should not be, therefore, overestimated. 


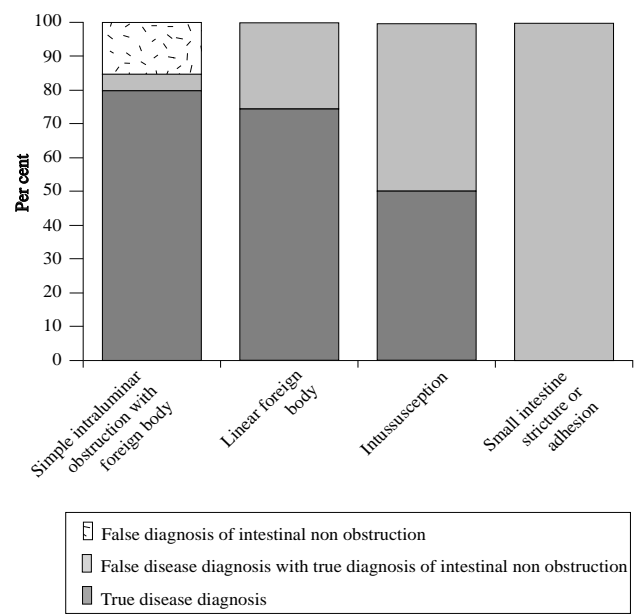

Fig. 1. Contribution of plain radiography to the diagnosis of specific small intestinal obstruction diseases examined by specialists in radiology
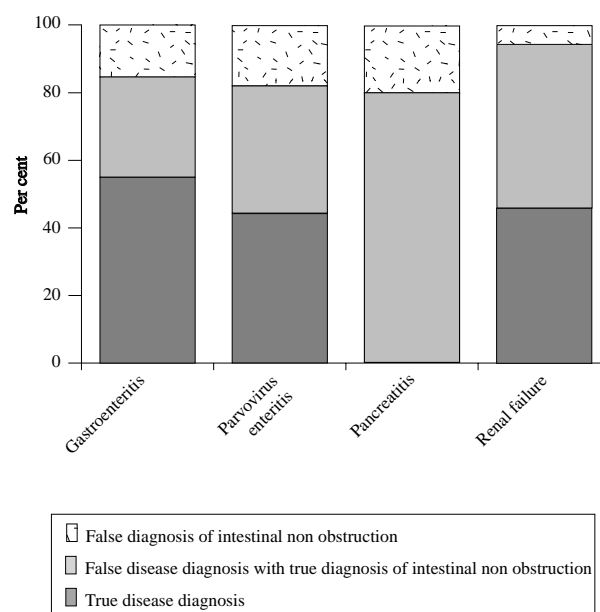

Fig. 2. Contribution of plain radiography to the diagnosis of specific small intestinal non-obstruction diseases examined by specialists in radiology

There were considerable differences in the diagnostic yield of plain radiography in individual diseases, although it would be necessary to evaluate much more numerous data to gain more precise results (Fig. 1, Fig. 2). The simple intraluminal obstruction by a foreign body ( 75 to $80 \%$ of cases) and the intestinal obstruction ( 80 to $85 \%$ of cases) seemed to give the highest diagnostic yield. The diagnostics of foreign bodies in the small intestine in previous studies was based either on their direct identification, because in a third of cases they were visible on plain radiographs (Clark 1968), or on observing intestinal dilatation proximally to the obstruction in $25 \%$ (Clark 1968) to $75 \%$ of cases (Gibbs and Pearson 1973). From our study it is clear that compiling all radiological signs it is possible to confirm the intestinal obstruction in a higher number of cases than in the above-mentioned ones. False negative diagnoses are then caused by foreign bodies of the soft tissue opacity or radiolucent ones (Gibbs and Pearson 1973) which are hard to visualise on plain radiographs. A partial obstruction not leading to considerable dilatation of small intestine proximally to the obstruction is another cause of a false negative diagnosis. Radiographs taken shortly after the onset of the obstruction may lack considerable dilatation of small intestine (Summers et al. 1983) because of the spasm of intestine and hypermotility in the prestenotic area due to the cholinergic stimulation and toxic effect of the intraluminal content.

Linear foreign bodies mostly result in a partial small intestinal obstruction and are characterized by opacity of a soft tissue. Their diagnostics using plain radiographs is thus much more difficult and to a great degree depends on the experience of the evaluating person (Root and Lord 1971; Gibbs and Pearson 1973), the fact being also evident from our study (Table 3).

Intussusception is difficult to recognize on plain radiographs. It can be evident as a sausage-like mass of soft tissue character situated mostly caudal to the right of the stomach. Depending on the degree of obstruction it can be accompanied by intestinal dilatation before the obstruction (Lew is and Ellis on 1987; Gibbs and Pearson 1973). According to one study there were no abnormalities found in 7 out of 19 cases on plain radiographs (Levitt and Bauer 1992). Regarding the fact that in our study there were only a few such cases, it 
would not be good to overestimate our results. Nevertheless, the precision of diagnosing the cause of obstruction and the diagnostics of small intestinal obstruction varied from 0 to $50 \%$ and 75 to $100 \%$, respectively.

Gastroenteritis and parvoviral enteritis in our experience are the most common diseases of the gastrointestinal tract that, on the initial clinical examination, are mistaken for small intestinal obstruction. Diagnostic imaging methods thus play an important role to exclude the intestinal obstruction as a cause of vomiting. The parvoviral enteritis and gastroenteritis were separated only for purposes of our study. In a clinical practice it is not possible to differentiate causes of gastroenteritis. The parvoviral enteritis typically occurs in young dogs and results in generalised changes of the gastrointestinal tract such as marked distension of the small intestine filled only by fluid. It is especially distension of the small intestine that may lead to a false diagnosis of the intestinal obstruction (Graham et al. 1998). In our study the false diagnoses of the intestinal obstruction in cases of gastroenteritis and parvoviral enteritis varied from 4.6 to $31.8 \%$ and 9.1 to $18.2 \%$, respectively.

Pancreatitis is another disease manifesting clinically as the intestinal obstruction. This disease cannot be mostly diagnosed using radiology, the fact also confirmed by results of our study because non of the evaluating persons in any of the cases of pancreatitis came to a correct diagnosis on the basis of plain radiography (Strombeck and Guilford 1991). In a clinical practice it should not be, however, omitted because, though not able to confirm the pancreatitis, it may help in up to $80 \%$ of cases to exclude the intestinal obstruction and thus the necessity of performing laparotomy.

Uremia due to renal failure may lead to a number of clinical signs and sometimes vomiting may be its only clinical symptom. It is mostly not accompanied by intestinal distension and other radiological signs of small intestinal obstruction. The number of false-positive diagnoses is therefore very low in our study (3.6 to10.7\% of cases). Depending on the experience of the evaluating person it is then possible to come to a correct diagnosis of the final disease in a number of cases using plain radiography. The true disease diagnosis varies from 21.4 to $46.4 \%$ of cases.

Plain radiography belongs to very important methods for diagnostics of small intestinal obstruction. In order to get high diagnostic yields it is necessary to evaluate the radiographs thoroughly and consider all radiological signs of the obstruction and be experienced. The diagnostic yield would be even higher, if the evaluating persons were provided with history, clinical signs and laboratory examinations. Plain radiography is thus without any doubt to be recommended as a simple and readily available diagnostic method for the intestinal obstruction which, in cases of the suspect intestinal obstruction, should precede all more demanding and expensive diagnostic methods.

\section{Přínos nativních rentgenogramů v diagnostice intestinální obstrukce u psů}

Do studie zjištující diagnostickou výtěžnost nativních rentgenogramů v diagnostice intestinální obstrukce s přihlédnutím ke všem rentgenologickým příznakům bylo zařazeno 53 psů s obstrukcí tenkých střev a 66 psů bez obstrukce. Nativní rentgenogramy byly posouzeny rentgenologem, chirurgem a internistou, přičemž zjištěné rozdíly v posouzení rentgenogramů jednotlivými posuzovateli nebyly statisticky významné. Přesnost nativních rentgenogramů v diagnostice intestinální obstrukce se pohybovala v rozmezí 80,7 - 89,1\%, senzitivita v rozmezí $76,8-87,0 \%$ a specificita v rozmezí $88,2-90,8 \%$. V př́ipadě, kdy byla diagnóza na základě nativních rentgenogramů označena rentgenologem jako definitivní, zvýšila se přesnost až na $96,9 \%$ a předpovězená hodnota pozitivní diagnózy na $100 \%$.

Vysokou výtěžnost měly nativní rentgenogramy v diagnostice jednoduché intraluminální obstrukce cizím tělesem ( 75 - 80 \% správných diagnóz) a obecně intestinální obstrukce (80 
- $85 \%$ ). Diagnostická výtěžnost u ostatních konkrétních př́čin intestinální obstrukce (lineární cizí těleso, invaginace a adheze nebo striktura) byla nižší a závisela velkou měrou na zkušenosti posuzovatele. Nativní rentgenogramy u onemocnění nevyvolávajících obstrukci tenkých střev (gastroenteritis, parvoviróza, pankreatitis a renální selhání) vedly ke správné diagnóze pouze v malém počtu prípadủ. Přesto měly nativní rentgenogramy velký význam ve vyloučení obstrukce tenkých střev, protože vykazovaly vysokou předpovězenou hodnotu negativní diagnózy $(80,3$ - 90,9\%).

Vzhledem ke zjištěným výsledkům lze nativní rentgenogramy doporučit pro diagnostiku intestinální obstrukce jako nenáročnou primární zobrazovací metodu.

\section{Acknowledgements}

This work was supported by the Ministry of Education, Youth and Sports of the Czech Republic (Research Project No. 161700002).

\section{References}

ARRICK, RH, KLEINE, LJ 1987: Intestinal Pseudoobstruction in a Dog. J Am Vet Med Assoc 172: 1201-1205 BOHMER, E, MATIS, U, ZEDLER, W, HANICHEN, T 1990: Small intestinal ileus in the dog and cat catamnestic observations of 704 patients. Tierarztl Prax 18: 171-83

CAIRÓ, J, FONT, J, GORRAIZ, J, MARTIN, N, PONS, C 1999: Intestinal volvulus in dogs: a study of four clinical cases. J Small Anim Pract 40: 136-140

CLARK, WT 1968: Foreign bodies in the small animal intestine of the dog. Vet Rec 83: 115-119

DENNIS, R, KIRBERGER, RM, WRIGLEY, RH, BARR, FJ 2001: Handbook of small animal radiological differencial diagnosis. W.B. Saunders, London, pp. 172-179

ELLISON, GW 1993: Intestinal obstruction. In: BOJRAB, MJ, SMEAK, DD, BLOOMBERG, MS. Diseases mechanisms in small animal surgery 2nd ed. Lea \& Febiger, Philadelphia, pp. 252-257

FAROW, CS 1997: The obstructive bowel pattern: An inconsistent radiographic sign of obstruction. Can Vet J 38 : 309-310

GIBBS, CH, PEARSON, H 1973: The radiological diagnosis of gastrointestinal obstruction in the dog. J Small Anim Pract 14: 61-82

GRAHAM, JP, LORD, PF, HARRISON, JM 1998: Quantitative estimation of intestinal dilation as a predictor of obstruction in the dog. J Small Anim Pract 39: 521-524

HENLEY, RK, HAGER, DA, ACKERMAN, N 1989: A comparsion of two-dimensional ultrasonography and radiography for the detection of small amounts of free peritoneal fluid in the dog. Vet Radiol 30: 121-124

HOSGOOD, G, BUNGE, M, DORFMAN, M 1992: Jejunal incarceration by an omental tear in a dog. J Am Vet Med Assoc 200: 947-950

KOIKE, T, OTOMO, K, KUDO, T, SAKAI, T 1981: Clinical cases of intestinal obstruction with foreign bodies and intussusception in dogs. Jpn J Vet Res 29: 8-15

LAMB, CR, MANTIS, P 1998: Ultrasonographic features of intestinal intussusception in 10 dogs. J Small Anim Pract 39: 437-441

LAMB, WA, FRANCE, MP 1994: Chronic intestinal pseudo-obstruction in a dog. Aust Vet J 71: 84-86

LEVITT, L, BAUER, MS 1992: Intussusception in dogs a cats: A review of thirty-six cases. Can Vet J 33: 660664

LEWIS, DD, ELLISON, GW 1987: Intussusception in Dogs and Cats. Compend Contin Educ Pract Vet 9: 523532

MANCZUR, F, VÖRÖS, K, VRABÉLY, T, WLADÁR, S, NÉMETH, T, FENYVES, B 1998: Sonographic diagnosis of intestinal obstruction in the dog. Acta Vet Hung 46: 35-45

McPHEDRAN, NT, HOLLIDAY, R, COLAPINTO, RF 1970: Angiographic diagnosis of strangulated bowel obstruction. Can J Surg 13: 90-92

MOORE, R, CARPENTER, J 1984: Intestinal sclerosis with pseudo-obstruction in three dogs. J Am Vet Med Assoc 184: 830-833

MYERS, NC, PENNINCK, DG 1994: Ultrasonographic diagnosis of gastrointestinal smooth muscle tumors in the dog. Vet Radiol Ultrasound 35: 391-397

PENNINCK, DG, NYLAND, TG, KERR, LY, FISHER, PE 1990: Ultrasonographic evaluation of gastrointestinal diseases in small animals. Vet Radiol 31: 134-141

ROOT, CR, LORD, PF 1971: Linear radiolucent gastrointestinal foreign bodies in the cats and dogs: Their radiographic appearance. J Am Vet Radiol Soc 12: 45-53

STROMBECK, DR, GUILFORD, WG 1991: Small animal gastroenterology. 2nd ed. Wolfe Publishing Ltd., London

SUMMERS, RW, YANDA, R, PRIHODA, M, FLATT, A 1983: Acute Intestinal Obstruction: An Electromyographic Study in Dogs. Gastroenterology 85: 1301-1306 
VÁLEK, V, CERALOVÁ, D, BOUDNÝ, D, MECHL, M, HROBAŘ, P 1997: Contemporary possibilities and position of imaging methods. Rozhl Chir 76: $258-262$

VÁLEK, V, HROBAŘ, P 1997: Comparison of the contribution of the sonografic examination of small bowel and enteroclysis in the diagnosis and the follow up of the Crohn's disease. European Radiology 7: 778

VÁLEK, V, SAIDA, Y, ITAI, K, MORI, K 2000a: Enteroclysis 1. Jap J Clin Radiol 45: 456-460

VÁLEK, V, SAIDA, Y, ITAI, K, MORI, K 2000b: Enteroclysis 2. Jap J Clin Radiol 45: 566-570

WILSON, GP, BURT, JK 1974: Intussusception in the Dog and Cat: A Review of 45 Cases. J Am Vet Med Assoc 164: $515-518$

WOLVEKAMP, WTC 1989: Enteroclysis. A new radiodiagraphic technique for evaluation of the small intestine of the dog. Iowa State University Press, Ames 